\title{
The Analgesic Effect of Pineapple Fruit Juice on Mice
}

\author{
Ainul Atiqah binti Hilmi ${ }^{1}$, Vycke Yunivita KD ${ }^{2}$, Henny Anggraini Sadeli ${ }^{3}$ \\ ${ }^{1}$ Faculty of Medicine, Universitas Padjadjaran, ${ }^{2}$ Department of Pharmacology and Therapy, Faculty \\ of Medicine, Universitas Padjadjaran, ${ }^{3}$ Department of Neurology, Faculty of Medicine, Universitas \\ Padjadjaran/Dr.Hasan Sadikin General Hospital
}

\begin{abstract}
Background: Pain is a feeling stimulated by the nervous system which can be suppressed by giving an analgesic agent. Some studies revealed that pineapples have an analgesic effect. This study aim was to determine analgesic effect of pineapple on mice.

Methods: In this experimental study, the effect was examined by using a writhing method on the 28 male mice. Subjects were divided into 4 groups with 7 mice each. The control group received aquades and other groups received pineapple fruit juice with $20 \%, 40 \%$ and $80 \%$ concentration with the dosage of $10 \mathrm{~mL} /$ $\mathrm{kg} /$ body weight. After 30 minutes, $3 \%$ acetic acid was injected intraperitoneally to induce pain. Writhing responseswere observed every 5 minutes for 30 minutes.

Results: The result for mean of total writhing reaction was $2.39 \pm 0.40,1.92 \pm 0.40,1.50 \pm 2.13,1.66 \pm 0.11$ respectively for group 1 to 4 . These data indicated a significant decrease of total writhing response in mice with $20 \%, 40 \%$ and $80 \%$ concentration compared to control group $(\mathrm{p}=0.023 ; \mathrm{p}=0.000$ and $\mathrm{p}=0.000$ respectively). Most optimal concentration was $40 \%$ with the protective percentage equal to $71.8 \%$.

Conclusion: Pineapple fruit juice concentrations (20\%, 40\%, and $80 \%$ has an analgesic effect with the most optimal concentration of 40\%. [AMJ.2014;1(2):100-4]
\end{abstract}

Key words: Analgesic, pain, pineapple fruit, writhing method

\section{Efek Analgesik Jus Buah Nanas Pada Mencit}

\section{Abstrak}

Latar Belakang: Nyeri adalah sensasi perangsangan sistem saraf yang dapat ditekan dengan pemberian zat analgetik. Penelitian sebelumnya menemukan bahwa nanas memiliki efek analgesik. Tujuan penelitian ini adalah untuk mengetahui efek analgesik nanas pada mencit.

Metode: Efek analgesik diperiksa dengan menggunakan metode "writhing" pada 28 mencit jantan. Subyek penelitian dibagi menjadi 4 kelompok masing-masing 7 ekor. Kelompok kontrol menerima aquades dan kelompok lainnya menerima jus buah nanas secara oral dengan konsentrasi $20 \%$, 40\% dan $80 \%$ dengan dosis $10 \mathrm{~mL} / \mathrm{kg} /$ berat badan. Setelah 30 menit, asam asetat 3\% disuntikkan intra peritoneal untuk menginduksi nyeri. Respons "writhing" diamati setiap 5 menit selama 30 menit.

Hasil: Hasil rata-rata reaksi total "writhing" adalah $2.39 \pm 0.40,1.92 \pm 0.40,1.50 \pm 2.13,1.66 \pm 0.11$ masingmasing untuk kelompok 1 sampai 4. Data ini menunjukkan penurunan yang signifikan dari jumlah respon "writhing" pada tikus dengan 20\%, $40 \%$ dan konsentrasi 80\% dibandingkan dengan kelompok kontrol ( $\mathrm{p}=0,023 ; \mathrm{p}=0,000 ;$ dan $\mathrm{p}=0,000$ masing-masing). Konsentrasi optimal adalah $40 \%$ dengan persentase pelindung sebesar 71,8\%.

Simpulan: Konsentrasi jus buah nanas (20\%, 40\% dan 80\%) memiliki efek analgesik dengan konsentrasi paling optimal pada 40\%. [AMJ.2014;1(2):100-4]

Kata Kunci: Analgesik, nyeri, nanas, writhing

Correspondence: Ainul Atiqahbinti Hilmi, Faculty of Medicine, Universitas Padjadjaran, Jalan Raya Bandung-Sumedang Km.21, Jatinangor, Sumedang, Indonesia, Phone: +6281912725563, +60199578082, Email: ainul_1908@yahoo.com.my 


\section{Introduction}

Pain is a feeling stimulated by the nervous system. It is a complex phenomenon that warns an individual about some tissue damage which currently is occurring or has occurred. ${ }^{1}$ It happens when there is a damage or injury, the tissue will release some chemical mediators such as bradykinin, and prostaglandin $\left(\mathrm{PGE}_{2}\right)$ which will stimulate pain sensation. 2 This sensation can be supressed by using analgesic drugs such as paracetamol and ibuprofen.

Some plants also exhibit analgesic effects such as pineapple (Ananascomosus). In previous study, pineapple had been proved as a plant that have an analgesic effect due to the presence of bromelain. ${ }^{3}$ This active compound which can be found in the root and stem of pineapple, bromelain, is a proteolytic enzyme which has many pharmacological activities such as analgesic agent, antiinflammatory, prevent edema, and increase tissue permeability of antibiotic drugs. ${ }^{4}$

In this study $3 \%$ acetic acid had been used to induce pain sensation on mice. Acetic acid is an irritation agent that when injected intraperitoneally, it usually induces hypersensitivity. ${ }^{5}$ The objective of this study was to determine the $20 \%, 40 \%$ and $80 \%$ of the pineapple fruit juice concentration which has the protective result as an analgesic effect.

\section{Methods}

The study subject used in this experiment were 28 healthy male mice (Musmusculus) with body weight of 20-30 gram each which then were divided into 4 equal groups. The research materials in this study were pineapple fruit juice as the intervention with the concentration of $20 \%, 40 \%$ and $80 \%$ for group 2, group 3 and group 4 respectively. To make $20 \%$ concentration of pineapple fruit juice, 20 gram pineapple was used. The pineapple was blended finely, filtered to get the juice and added with $100 \mathrm{~mL}$ distilled water. For concentration of $40 \%$ and $80 \%, 40$ gram and 80 gram of pineapple fruit were used respectively and then the same procedure was applied.

Other materials used were $3 \%$ acetic acid as the pain stimulation and aquades as placebo. All mice were left freely for one week as an adaptation period in the laboratory with optimal room temperature without any effort of intervention. Prior to the experiment, all mice must undergo a fasting period for 18 hours with free access of drinking water. ${ }^{6}$

Writhing method or abdominal contraction method was used in this study to evaluate the analgesic effect. For the experimental group, each will receive $20 \%, 40 \%$ and $80 \%$ pineapple fruit juice concentration respectively via oral and for thecontrol group, aquades was givenorally as a placebo. After 30 minutes, $30 \%$ acetic acid was injected intraperitoneally to induce pain. Right after acetic acid was given, writhing response was observed. The reaction was observed for 5 minutes every 30 minutes right after giving acetic acid. The writhing reflexes observed on mice included abdominal contraction, stretching of the body, retraction of the abdomen followed by withdrawing of the lower limbs backward. ${ }^{7}$

Protective percentage in this study was calculated by using the formula of $100 \%$ (total number of writhing in experimental group / total number of writhing in control group) $x 100$. For statistical analysis, analysis of variance (ANOVA) was used to see whether significant differences between groups. The test then subjected to Tukeyy HSD multiple comparison post test.

This experiment was done in November 2012attheAnimal Laboratory of Pharmacology and Therapy, Faculty of Medicine, Universitas Padjadjaran , Jatinangor, Bandung, Indonesia.

\section{Results}

In this study, the data was analysed by using Shapiro-wilk test to find its distribution and due to data skewness original data of mean of total writhing reaction in mice was transformed into a new data to meet the criteria of parametric test ANOVA..The formula used was $((\sqrt{ }(\mathrm{x}+1))$. The new data has been recorded in table 1 .

Table 2 showed a presence of significant difference $t$ in each group with significant value of $0.000(\mathrm{p}<0.05)$. Post hoc test by using Tukeyy HSD method was conducted to find out in which group the significant difference can be found (Table 3).

All three experimental groups showed significant reduction in total number of writhing response comparing to control group (Table 3). It means that the analgesic activity was significantly different from the control group $(p<0.05)$, while in three experimental group, there was only a significant difference between group 2 and $3(p<0.05)$.

Pineapple fruit juice with concentration of $40 \%$ show ed the most protective effect as an analgesic than other,which was $71.8 \%$. 
Table 1 Mean of total writhing reaction in mice

\begin{tabular}{ccc}
\hline Groups & Mean of total writhing reaction in mice & SD \\
\hline 1 & 2.39 & 0.40 \\
2 & 1.92 & 0.26 \\
3 & 1.50 & 2.13 \\
4 & 1.66 & 0.11 \\
\hline
\end{tabular}

Group 1 : given aquades

Group 2 : given $20 \%$ pineapple fruit juice concentration

Group 3 : given $40 \%$ pineapple fruit juice concentration

Group 4 : given $80 \%$ pineapple fruit juice concentration

Table 2 Difference Total Writhing Reaction Between Groups

\begin{tabular}{cccccc}
\hline & Group 1 & Group 2 & Group 3 & Group 4 & P \\
\hline $\begin{array}{c}\text { Mean of total } \\
\text { writhing reaction } \\
\text { in mice }\end{array}$ & 2.39 & 1.92 & 1.50 & 1.66 & 0.000 \\
\hline
\end{tabular}

Then, it was followed by $80 \%$ concentration which was $61.6 \%$ and the last one was $20 \%$ pineapple fruit juice concentration which was $35.4 \%$ (Table 4 ).

\section{Discussion}

Based on its pathophysiology, pain can be classified into three types which are somatic, visceral and neuropathic pain.8 Somatic pain is usually located at the peripheral, visceral pain involves intra-abdominal organ, and neuropathic pain involves afferent neural pathway. ${ }^{8}$

This study was conducted to examine the analgesic effect of the pineapple fruit (Ananascomosus) juice on the mice models. The analgesic reactions were measured by the total number of writhing in the mice every 5 minutes for 30 minutes. The mean of total writhing reaction in mice was decreasing from the mean group until group 3 which received $40 \%$ concentration of pineapple fruit (Ananascomosus) juice and increased again in the group 4 when the mice in this group had $80 \%$ concentration of pineapple fruit juice (Table 1). This condition showed that the pineapple juice had a ceiling effect. Ceiling effect is a condition where at certain dosage, the drugs does not give any therapeutic effect instead this condition can increase the side effect.9Because of the ceiling effect, $80 \%$ concentration of pineapple fruit juice show ed decreasing analgesic effect.
There was a significant difference between control group and experimental groups which received $20 \%, 40$, and $80 \%$ pineapple fruit juice concentration (Table 2 and 3). It revealed that at all concentrations, pineapple fruit juice showed its analgesic effect by reducing the bradykinin synthesis. But there was only a significant difference between group 2 and 3 in the experimental groups. Almost all analgesic drugs prevent the $\mathrm{PGE}_{2}$ formation by inhibiting the activity of cyclooxygenase (COX) which is the enzyme responsible for $\mathrm{PGE}_{2}$ synthesis. ${ }^{10}$ In establishing the analgesic effect, bromelain will decrease the bradykinin level released when tissue is damaged. Bradykinin will stimulate the production of prostaglandin while prostaglandin in turn will enhance the sensitivity of bradykinin toward its receptor. ${ }^{2}$ When bradykinin is low, it also will decrease the $\mathrm{PGE}_{2}$ synthesis and decrease the pain. ${ }^{11}$

Moreover, comparison between group 2 (20\% concentration of pineapple juice) and group $3 \quad 40 \%$ concentration of pineapple juice) revealed a significant difference. From the protective percentage measurement, the result show ed that pineapple fruit juice with concentration of $40 \%$ ha d the most protective result.

Previously, there had been studies upon the effect of bromelain extract of pineapple stems towards the analgesic reaction in mice. The chemical constituent responsible for analgesic effect is known as bromelain which is a proteolytic enzyme. This active compound 
Table 3 Post hoc test by Tukeyy HSD method

\begin{tabular}{ccc}
\hline $\begin{array}{c}\text { Group } \\
\text { Comparison }\end{array}$ & P & SD \\
\hline 1 & 2 & 0.023 \\
1 & 3 & 0.000 \\
1 & 4 & 0.000 \\
2 & 3 & 0.042 \\
2 & 4 & 0.310 \\
3 & 4 & 0.696 \\
\hline
\end{tabular}

Note:

Group 1 : given aquades

Group 2 : given $20 \%$ pineapple fruit juice concentration

Group 3 : given $40 \%$ pineapple fruit juice concentration

Group 4 : given $80 \%$ pineapple fruit juice concentration

Table 4 Protective percentage against $3 \%$ acetic acid

\begin{tabular}{ccc}
\hline Group & Total writhing & Protective percentage (\%) \\
\hline Aquades & 206 & 0 \\
$20 \%$ pineapple juice & 133 & 35.4 \\
$40 \%$ pineapple juice & 58 & 71.8 \\
$80 \%$ pineapple juice & 74 & 61.6 \\
\hline
\end{tabular}

is present in the stem as well as in the fruit. From the data in this study, we can conclude that the pineapple fruit also has an analgesic activity like the stem. But to ensure the safety issue, several studies should be addressed to reveal the side effect, toxicity, minimum and maximum dosage of pineapple fruit as an analgesic. Other studies can also be conducted to compare the pineapple fruit to other nonopioid analgesic that are commonly used in the community such as paracetamol and ibuprofen

\section{References}

1. Continuum Health Partners.Definition and type of pain.[Online Web Page] 2011 [cited 2012 April 15]. Available from: http:// www.healingchronicpain.org/content/ introduction/definitions.asp.

2. Bueno L, Fioramonti J. Visceral perception: inflammation and non-inflammatory mediators.BMJ. 2002;51(Suppl1): S19-23.

3. Sudjarwo SA. Anti-inflammatory and analgesic effect of bromelain in mice and rats.Universa Medicina. 2005;155-60.
4. Bhattacharyya BK. Bromelain: an Overview. Nat ProdRadiance.2008;7(4):359-63.

5. Bueno L, Fioramonti J, Garcia-Villar R. Visceral afferent pathways: a source of new therapeutic targets for abdominal pain. APS. 2000;278(5):670-6.

6. Smith A. Fasting in rodents. NorecopaVeterinaer Institute; 2009 [cited 2012 May 8]. Available from: http://www. norecopa.no/norecopa/vedlegg/Fooddeprivation.pdf.

7. Sureshkumar S, Sivakumar T, Chandrasekar $M$, Suresh B. Investigating the antiinflammatory and analgesic activity of leaves of wedeliachinensis (osbeck) merr. In standard experimental animal models. IJPR. 2006;5:123-9.

8. Cole BE. Pain management: classifying, understanding, and treating pain. Hosp Phys. 2002;23-30.

9. Aschenbrenner DS, Venable SJ. Drug in nursing. 3rd ed. Philadelphia: Lippincott William \& Wilkins; 2009.

10. Vane JR, Botting RM. The mechanism of action of aspirin.ThrombRes. 2003;255-8.

11. Brien S, Lewith G, Walker A, Hicks SM, Middleton D. Bromelain as a treatment for 
osteoarthritis: a review of clinical studies.

Evid Based Complement Alternat Med.

2004;1(3):251-7. 